\title{
Estado e Higienismo Versus a Velha Ordem Estamental Brasileira. Uma relação produto da modernização capitalista
}

\author{
State and Social Medicine Against the Old Brazilian Order Before the Capitalism. A \\ Relation Product of the Capitalist Modernization
}

\section{Vinicius Bandera}

Resumo: O nosso escopo é mostrar a origem e o desenvolvimento do higienismo na cidade do Rio de Janeiro. A hipótese a ser demonstrada é que essa origem e desenvolvimento foram resultantes da modernização capitalista, que promoveu um grau significativo de urbanização, provocando o aumento populacional nas principais cidades brasileiras a partir do último quartel do século XVIII e, por conseguinte, um aumento de insalubridade, doenças e mortalidade. A mesma modernização capitalista que foi a principal responsável pela criação desse caos sanitário exerceu o protagonismo de combatê-lo, através de políticas públicas sanitaristas levadas a efeito pela aliança entre o Estado e a medicina social, do que resultou o higienismo.

Palavras-chave: Medicina social/higienismo. Construção do Estado nacional brasileiro. Modernização contra tradição.

Abstract: The kernel of this text is to show the origin and development of the hygienism in Rio de Janeiro. The hypothesis to be demonstrated is that this origin and development were resulting from the capitalist modernization, which promoted a significant degree of urbanization, causing the increase in population in the main brazilian cities from the last quarter of the I8th century and, therefore, an increase of unsanitary conditions, diseases and

\footnotetext{
Pós-doutorado em História Social (USP). Doutorado em Sociologia (UFRJ). Mestrado em Ciência Política (UNICAMP). Instrutor da Polícia Militar do Estado do Rio de Janeiro na Escola Superior de Polícia Militar e na Academia de Polícia Militar.
} 
mortality. The same capitalist modernization that was the main responsible for the creation of this chaos had the protagonist role to combat it through health professionals public policies carried out by the alliance between the State and social medicine, which resulted the hygienism.

Keywords: Social medicine/hygienism. Construction of the national brazilian State. Modernization against tradition.

\section{Introdução}

Nos três primeiros séculos de nossa história, a prática de curar não era uma exclusividade dos médicos. O meio colonial não se mostrava propício ao desenvolvimento da ciência médica. O Brasil de então, isto é, a América Portuguesa, estava sob significativa influência dos valores rurais, os quais traziam em si um cunho tradicionalista, empirista, anticientífico. Era um território dividido em diversos domínios rurais, isolados uns dos outros, sob o beneplácito absolutista de seus respectivos senhores patriarcais e patrimonialistas. As poucas cidades iam surgindo em função desses domínios, como meio de escoar produtos primários, administrar a vida pública e fortalecer e estender a dominação tradicional (WEBER, I979, p.I3I-I35) que já existia nos domínios rurais. Não havia, portanto, sobretudo nos séculos XVI e XVII, um ambiente auspicioso ao desenvolvimento da ciência médica. De maneira que, os primeiros médicos estavam em um plano de competência equivalente àquelas pessoas que exerciam a "medicina" tradicionalmente: os curandeiros indígenas ou africanos, os barbeiros, os charlatães e os padres. O fato de a medicina ainda não ter alcançado um considerável grau de certeza, debilitava-a frente às práticas curativas suas concorrentes. Não havia um controle preventivo para as doenças; sequer havia um efetivo e racional registro dos doentes, dando conta de seu histórico enquanto assistido. A arte de curar - era mais arte do que ciência somente intervinha sobre a pessoa, de modo geral, quando ela estava sob o domínio da doença. E o fazia mais como forma de dar-lhe um alívio em seu estado terminal, do que fazê-lo voltar à normalidade.

A cidade do Rio de Janeiro se desenvolveu de forma desordenada. Foi concentrando mais e mais contingentes populacionais, que vinham do campo, do exterior (europeus e 
escravos africanos), de vilas e cidades menores. Esse aglomerado de gente passou a gerar ainda mais insalubridade do que aquela que a própria natureza proporcionava, através dos muitos pântanos que exalavam miasmas, ares fétidos, como veremos ao longo deste texto. Não havia, até meados do século XIX, esgoto e água nas casas. Os excrementos eram acumulados num barril dentro de cada residência, o qual, depois de cheio, era levado pelos escravos e lançado às praias, aos pântanos ou quaisquer outros lugares. Cadáveres eram abandonados às ruas e em terrenos baldios. Da mesma forma que acontecia com animais mortos. Surtos de epidemia, dos quais a febre amarela foi a mais devastadora, acometiam a população carioca durante os séculos XVIII e XIX. Outra prática comum contra a higiene pública consistia no sepultamento de pessoas em covas rasas de terrenos de igrejas e hospitais, além de outros quaisquer terrenos.

A velha ordem senhorial não tinha uma resposta para esse caos de insalubridade, mesmo porque o seu habitat tradicional provinha do meio rural. Um elemento exógeno viria a ser o principal causador de uma atitude intervencionista nesse caos urbano. Estamos referindo-nos à modernização capitalista advinda da Europa, prenhe de racionalidade, que trouxe urna carga forte de higienismo para juntar-se ao higienismo incipiente que já se estava desenvolvendo no Rio de Janeiro (também em outros lugares do Brasil), levado a efeito sobretudo pela Academia Imperial de Medicina e pela Faculdade de Medicina do Rio de Janeiro. A essa altura, início do século XIX, a medicina, como ciência, já vinha ganhando espaço sobre a "medicina alternativa", a despeito desta ainda ser uma concorrente ameaçadora.

A vinda da Corte para o Brasil, especificamente para o Rio de Janeiro, foi um fator preponderante de avanço da ciência, das luzes. Com D. João VI, ao contrário do que acontecera com os nossos primeiros descobridores/conquistadores, veio o que existia de mais ilustrado em Portugal. Houve, para o Brasil e, principalmente, para o Rio de Janeiro, um grande salto de qualidade em direção à nova ordem, mais racional, científica, higienista. Sem termos forjado o iluminismo, sem termos participado de sua construção, recebemos urna importante síntese dele, através da imigração da Corte. Síntese essa representada pela importação de um grande número de pessoas ilustradas, desde artistas até cientistas, passando por administradores, teóricos e consumidores da cultura iluminista. Em pouco tempo, o Rio de Janeiro foi ganhando museus, bibliotecas, academias... A influência europeia fez-se sentir não 
mais através de livros clandestinos, como à época das rebeliões nativistas, mas diretamente, no cotidiano das reuniões de intelectuais, nas festas da corte.

Esse caldo cultural deu-nos uma larga base para fazermos a nossa Independência e construirmos uma sociedade e um Estado nacional, embora com dependências econômica e cultural, o que tem sido a nossa tradição. O tipo de modernização trazido pela Corte iria penetrar cada vez mais em nosso país na pós-Independência. Isto enfraqueceria pari passu a velha ordem e fortaleceria o avanço, ainda que incipiente, da ciência. Os senhores rurais, não obstante continuassem a ser os chefes econômicos e políticos da nação, teriam os seus valores contrapostos aos novos valores modernizadores, com base na razão científica, que pregavam a ordenação do caos, através do planejamento urbano, do controle racional e preventivo às doenças, atuando em suas causas, propondo aterramento dos pântanos, criação de redes de água e esgoto domésticos, criação de cemitérios e proibição de sepultamentos em igrejas e hospitais, fiscalização dos matadouros e da venda de comida (principalmente a carne), vacinações em massa como forma de prevenir doenças, etc.

No corpo do Estado estavam pessoas, em grande parte, caudatárias dessa modernização, embora fossem, em sua maioria, prepostos dos senhores rurais, muitos dos quais seus parentes, filhos, sobrinhos, genros, afilhados. A medicina, com ganhos substantivos em graus de certeza, fortaleceu sobremaneira essa cultura cientificista advinda da modernização capitalista. O higienismo foi o ramo da medicina social que mais despontou a essa época, devido, sobretudo, ao caótico estado de insalubridade da cidade.

Passou a haver, diante das condições materiais de então, uma comunhão de interesses entre homens do Estado e da ciência. Comunhão essa que os contrapunha aos senhores rurais. Formou-se, assim, a aliança do Estado, que se vinha aburguesando, com o higienismo contra a velha ordem. O primeiro já vinha desenvolvendo um controle social sobre os marginais, isto é, os vadios, os mendigos e outros desviantes da ordem. A proposta higienista veio reforçar de uma forma racional o controle social monopolizado pelo Estado. O higienismo equivalia à aplicação do poder disciplinar (FOUCAULT, 2004), aquele que penetra nos interstícios do corpo social, nas instituições de sequestro (FOUCAULT, 1976), na família, atingindo cada indivíduo especificamente. As campanhas de vacinação e as visitas sanitárias domiciliares foram duas maneiras básicas pelas quais o higienismo se expressou, desvendando lares, lojas, manufaturas, fábricas e instituições sociais, de forma a impor um controle bem mais eficaz do que a mera ação repressiva com que tradicionalmente o Estado operava. 
Utilizamos o método dialético para alicerçarmos a investigação de nossos objetivos, que são mostrar que a modernização brasileira foi decorrente da modernização europeia e que ambas as modernizações condicionaram o Estado e o higienismo a se aliarem contra a ordem estamental que se mostrava incapaz de encetar um combate eficaz contra o caldo cultural de insalubridade formado nos três primeiros séculos de colonização.

\section{O engatinhar da medicina}

$\mathrm{Na}$ introdução, tivemos a oportunidade de ressaltar que a América Portuguesa era constituída, no processo de colonização, basicamente por domínios senhoriais, predominantemente rurais. Tais domínios eram autóctones e em cada um reinava diretamente a vontade de seu senhor; embora, indiretamente, tudo fosse subordinado à Coroa. No entanto, o poder real, malgrado ter maior peso hierárquico - peso absolutista, diga-se de passagem -, estava bastante distante fisicamente daqueles domínios e da América Portuguesa como um todo. Na prática, o senhoriato de terras e escravos representava o coletivo dos chefes patrimonialistas da Colônia. Estes eram a classe dominante a impor a sua ideologia como dominante, tanto em sua ordem privada, quanto na engenharia político-administrativa que dirigia a pouca ordem pública de então. Era como se ainda não houvesse Estado; sendo este quase uma abstração, pois estava na Metrópole a muitas milhas e dias de distância. Os prepostos estatais na Colônia, isto é, os representantes do rei, também não tinham a agilidade administrativa de penetrar nos interstícios da vida colonial. Não havia ainda o que Foucault chama de poder disciplinar, mas o poder baseado na soberania (FOUCAULT, 2004), que controla de longe, com pouca eficiência em fazê-lo. De modo que, as ordens privadas sobrepunham-se à pouca ou quase nenhuma ordem pública. Era uma sociedade, ou melhor, várias sociedades, sem luzes iluministas. Havia uma dominância da rudeza dos costumes, como também já tivemos o ensejo de destacar anteriormente. A meta principal dos que para aqui vinham não era a de construir uma nação, mas a de saquear um território, enriquecer-se rapidamente e voltar para a Metrópole com o produto do saque; embora a nível de Estado português dois dos objetivos precípuos fossem o povoamento e a defesa da conquista.

Todo este preâmbulo é para assinalar que nesse caldo cultural não poderia haver um lugar meritório para a ciência do corpo, isto é, a medicina - que ainda estava em fase embrionária - e, menos ainda, para o fenômeno dela decorrente no século XIX: o higienismo. 
A medicina colonial estava no mesmo nível "científico" que as crendices levadas a efeito pelos curandeiros, pajés ou jesuítas; estes últimos, inclusive, "foram preferidos como médicos aos próprios profissionais" (SANTOS FILHO, s/d, p.8I).

Os jesuítas "sangravam, purgavam, operavam, assistiam, curavam, sob qualquer forma”, e, como decorrência da aculturação - a qual não impede de todo a influência cultural do colonizado -, também recorriam ao "empirismo indigena" (ROCHA, 1947, p.36). Um documento fundamental que regulamentava a assistência dos jesuítas a doentes e pobres era o "Compromisso da Ordem, datado de I5I6" (VIOTTI, 20I2, p.I7).

Os médicos não tinham ainda o poder que viriam a ter no século XIX. Eram de classe baixa, de condição humilde e pouca instrução. Quem exercia a medicina eram homens de pouco valor na rígida estratificação, de base estamental (SANTOS FILHO, s/d, p. 48).

Com o tempo, outros profissionais, como os boticários, os charlatães, os entendidos, os curiosos, os barbeiros e os cirurgiões-barbeiros, viriam a concorrer com os médicos. Os barbeiros e os cirurgiões-barbeiros se ocupavam, como sugerem suas denominações, de cuidar de barbas e cabelos. Entretanto, eram também profissionais de "medicina"; receitavam medicamentos, aplicavam ventosas e sanguessugas, faziam pequenas cirurgias - os segundos e curativos (Ibid., p.I45).

No Rio de Janeiro como em Lisboa as lojas de barbeiros, copiadas das espanholas, apresentam naturalmente o mesmo arranjo interior e o mesmo aspecto exterior com a única diferença de que o oficial de barbeiro no Brasil é quási sempre negro ou pelo menos mulato. Esse contraste chocante para o europeu não impede ao habitante do Rio de Janeiro entrar com confiança mima dessas lojas, certo de aí encontrar numa mesma pessoa um barbeiro hábil, um cabeleireiro exímio, um cirurgião familiarizado com o bisturi e um destro aplicador de sangue-sugas. Dono de mil talentos, ele tanto é capaz de consertar a malha escapada de uma meia de sêda, como de executar, no violão ou na clarineta, valsas e contradansas francesas, em verdade arranjadas a seu jeito. Saindo do baile e colocando-se a serviço de alguma irmandade religiosa na época de uma festa, vemo-lo sentado, com cinco ou seis camaradas, num banco colocado fora da porta da igreja, executar o mesmo repertório, mas desta feita para estimular a fé dos fiéis que são esperados no templo onde se 
acha preparada uma orquestra mais adequada ao culto divino (DEBRET, I940, p. I5I).

Pelo que vimos até aqui, fica-nos a preocupação de termos passado a impressão de que os barbeiros eram uma opção marginal de tentativa de remediar os males do corpo. Opção levada a efeito por pessoas pobres e de baixo grau de instrução e de informação, analfabetos em sua grande maioria. No entanto, para termos uma ideia do baixo grau de certeza da medicina acadêmica e do considerável prestígio social (não somente entre os ignorantes) dos barbeiros, julgamos conveniente citar o trecho abaixo, o qual serve de complemento ao trecho de Debret, que acabamos de apresentar, e também de exercício genealógico.

Armados em sangradores, brevemente passaram a exercer as funções de cirurgiões. Em alguns países, os reis chegaram a protegê-los escandalosamente. Assim, em Londres organizaram-se os barbeiros em colégio especial, usufruindo privilégios e garantias outorgados pelo rei Eduardo IV, em I462. O mesmo ocorreu na França, Itália, Portugal e outros países da velha Europa. Em Portugal, desde a monarquia, os barbeiros exerciam também a profissão de sangradores e cirurgiões, obtendo, após prática e exame, a respectiva carta. No ano de I604, surgiu, neste país, uma obra que se tornou clássica entre os profissionais da navalha: Prática de barbeiros em 4 tratados, em os quais se trata de como se há de sangrar e as coisas necessárias para a sangria e juntamente se trata em que parte do corpo humano se hão de lançar as ventosas assi secas como sarjadas... com outras muitas curiosidades pertencentes para tal ofício. Era tal o domínio exercido pelos barbeiros no ânimo do povo, que os médicos se queixavam amargamente por verem suas opiniões preteridas em favor dos diagnósticos dados por tais profissionais. "E o pior, dizia um dos lamentadores, é que se dois ou quatro médicos disserem ao enfêrmo que não tem febre, e vier o barbeiro e disser que a tem, lhe dão mais crédito aos ditos médicos”. Isto tudo era reflexo do atraso em que se achava a medicina daquele tempo. Certo personagem, que viveu nessa época, não estava longe da verdade ao afirmar que os médicos "curavam por ignorância e matavam por experiência".

\footnotetext{
${ }^{1}$ Sem autoria. Setembro 1960. "Rio pitoresco XII. Os barbeiros". Avante, p.8.
} 
Havia uma escassez de médicos na colônia. Aqui é necessário abrir um parênteses para sublinhar que a função de médico era a de remediar; não existia uma medicina preventiva. $\mathrm{O}$ médico, ou seus similares, normalmente só era procurado em caso de doença; às vezes quando o doente já estava em estado terminal. Nesses casos, chamavam o médico e o padre, tendo este uma importância maior. Aliás, o segundo tanto podia prestar uma assistência espiritual quanto medicinal, sobretudo se fosse jesuíta. Os religiosos, fossem ordenados ou leigos, tinham uma espécie de exclusivismo na área da assistência social. Sobre a escassez de médicos, Roberto Machado et al constataram-na através de cartas de pessoas que reclamavam a presença de um profissional de medicina em suas cidades ou vilas (MACHADO ET AL., I987,p.22).

Nos primeiros dois séculos da colônia, para se exercer o oficio de curar bastava a vontade de fazê-lo e obter reconhecimento público no local em que atuasse. Posteriormente, seguindo a praxe que se processava na Europa, passou a haver a necessidade de se tirar licença para ser um profissional oficial de medicina. E essa licença veio a ser uma decorrência do empirismo que já vigia desde os primeiros tempos coloniais. Ou seja, para ser habilitado como cirurgião ou farmacêutico - basicamente estes dois misteres -, bastava tão-somente uma comprovação da prática em hospital ou botica de no mínimo quatro anos (ROCHA, 1947, p.39). Donde se depreende que o que se legalizava não era uma ciência propriamente dita, tampouco um cientista, mas o empirismo que já vigia, embora o colocando sob um controle racional. Essa licença, já no século XVIII, era concedida por um órgão estatal de saúde pública: a Real Junta do Proto-Medicato, criada em I7 de junho de I782 (VIOTTI, 20I2, p. 22) . Como a grande maioria dos que exerciam a medicina eram os curandeiros, sangradores, charlatães, boticários, barbeiros, parteiras, entre outros práticos, naturalmente eram estes a obter o maior número de licenças, embora também a obtivessem uma minoria de médicos diplomados em Coimbra e os médicos práticos que já atuavam no Brasil (ROCHA, I947; NASCIMENTO, I9I5; NASCIMENTO, 1929).

Os médicos iam clinicando isoladamente, ao longo do período colonial, sofrendo a concorrência dos "paramédicos”. Faziam-no a nível de medicina privada, na relação médicopaciente. Não tinham ainda ingerência nas políticas sociais de saúde. Estas, incuriosas e incipientes, ficavam a cargo de cada municipalidade, no caso das cidades, e praticamente não existiam em se tratando de territórios rurais. Uma das primeiras formas de organização 
classista dos médicos foi a já mencionada Real Junta do Proto-Medicato. Mas esta não tinha, ainda no século XVIII, a força que a denominação pode sugerir. Nessa época, a Junta não era co-partícipe das políticas públicas de saúde que o Estado, isto é, o Senado da Câmara, formulava e implementava. Os políticos até ouviam os médicos - o que era um avanço em relação aos primórdios coloniais -, mas isoladamente, como espécie de consultores técnicos (MACHADO ET AL.,I987). De modo que, no século XVIII, a regra geral era os políticos equacionarem soluções para questões de saúde pública e os médicos continuarem a atuar confinados à saúde privada. Isto iria mudar a partir do momento em que a saúde passou a ser um objeto de Estado, uma questão de biopolítica, como veremos.

\section{O caos de insalubridade na cidade do Rio de Janeiro}

A saúde pública não era tratada, durante todo o período colonial, como objeto fruto da ciência médica. Não havia ainda uma medicina social, o que fazia com que se perpetuasse na cidade do Rio de Janeiro, e em outras cidades brasileiras, velhos vezos antihigiênicos que datavam da Idade Média e se instalaram na Colônia com o descobrimento. Em outras palavras, eram comuns os sepultamentos em covas rasas nos terrenos das igrejas, hospitais e quintais domésticos, o lançamento de excrementos em praias, pântanos e terrenos baldios, a falta de coleta de lixo por parte da municipalidade, etc., ingredientes que transformavam a cidade em um caos sanitário. O gradativo aumento da população e a consequente expansão dos limites urbanos, à base de uma proliferação de habitações mal ordenadas, só faziam agravar o problema, exigindo prementes providências que, para além de paliativas, trouxessem uma profilaxia saneadora. O Rio de Janeiro era uma cidade que crescia sem planodiretor, produzindo um amontoado de ruas estreitas e casas mal arejadas, meio propício ao fomento e à rápida propagação de doenças contagiosas. O fato de ter sido edificada em áreas pantanosas era um grave fator a produzir insalubridade, causada pelas águas estagnadas, que exalavam um odor prejudicial à saúde e com as chuvas transbordavam pela cidade. Em I808, o físico-mor do reino, Manoel Vieira da Silva, colocava as águas pantanosas como ocupando o “principal lugar entre as causas da insalubridade” da cidade (apud SILVA, I977, p.96).

Segundo um depoimento da época 
A cidade do Rio de Janeiro ou, para dar o seu nome por extenso, São Sebastião do Rio de Janeiro, é, na maior parte, construída sobre terreno plano e baixo, mas estende-se também sobre diversas pequenas colinas, que sobem da beira do mar, tanto ao norte, quanto ao sul, desse espaço plano. As ruas são bem retas, mas, em geral, cheias de abomináveis odores; as calçadas são horrivelmente toscas e parecem como se nunca tivessem sido consertadas (BUNBURY, I940, p.I6).

Ainda não havia, durante todo o período colonial e grande parte do período imperial, água encanada nas residências, sendo isto um estorvo a uma eficaz higiene corporal, fazendo com que fosse comum o costume das pessoas abusarem do consumo de extratos, loções e perfumes para suprir a "falta do líquido precioso" (RENAULT, I978, p.56). Os aguadeiros geralmente escravos - iam buscar água em fontes públicas, que também serviam para abastecer os cavalos e outros animais.

Se não existia água encanada é dedutível supor que o mesmo também ocorresse em relação à rede de esgotos, e nisso residia uma grande causa de insalubridade para a cidade como um todo. Na verdade, "as primeiras obras de esgotos da cidade do Rio de Janeiro datam dos tempos coloniais" (FARINHA, I883, p.I3); entretanto, não faziam ligações domésticas, destinavam-se a escoar as águas naturais e pluviais. Segundo Charles Ribeyrolles, um visitante estrangeiro ao Brasil colonial, "o esgoto mata a cidade, em vez de sanear", porque os canos eram mal conservados e entupiam com facilidade, represando as águas e provocando acúmulo de sujeiras e de mau cheiro, fatores de risco à saúde pública. Quando chovia a situação se deteriorava ainda mais: os esgotos e as águas represadas transbordavam; juntando-se às águas dos pântanos, do mar e das encostas, descendo estas últimas pelo declive das ruas. O próprio Ribeyrolles atenua a responsabilidade da administração pública, reconhecendo que o fato de a cidade estar quase ao nível do mar era um empecilho natural à resolução dos transtornos que estamos comentando (Ribeyrolles, I94I, p.I52).

Pior do que esse mau esgotamento das águas era a falta de esgotos domiciliares, o que fazia com que as pessoas acumulassem em casa, em barris apropriados, as suas fezes e urinas, que, posteriormente, eram transportadas por escravos e lançadas ao mar, aos pântanos ou mesmo em terrenos baldios. Os barris eram conservados em determinado cômodo da casa, exhalando 
vapores provenientes da fermentação, que vão ainda mais saturando o ar, já bastante depauperado de oxigenio, com acido carbonico, azoto, etc.; e descobertos ou mal tampados ali permanecem por muitos dias até que cheios são conduzidos por pretos para serem lançados no litoral, quando não em algum canto de nossas ruas (LEITE, I849,p.4-5).

Em relatório de I6 de março de I869, portanto a poucos anos do século XX, o Barão do Lavradio, então Presidente da Junta Central de Saúde Pública, descrevia, até de forma hilária, como os escravos transportavam os barris.

Quem viu esses batalhões de carregadores, atravessando a passo accelerado por certas ruas, como as da Guarda Velha, Ajuda, Ouvidor, Rosario, e outras, compostos em sua maior parte de escravos e pretos libertos, já velhos, estropiados e bebados, que encontram nesse trabalho um meio mais lucrativo do que em outros; alguns dos quaes pareciam a cada momento precipitar-se com a carga pesada que conduziam, atropellando a todos que passavam; e que procuravam livrar-se de uma catastrophe desagradavel, não pode ainda hoje deixar de estremecer á lembrança dos sustos por que passou de ser assaltado por um tigre (expressão vulgar com que se designavam os barris cheios de materiais "fecaes" (apud FARINHA,I883,p.I8-I9).

Ribeyrolles chama esses batalhões, dos quais "a população se afasta", de "o cortejo do tigre" (RIBEYROLLES, I94I, p.I53). Cabungo era outro nome que recebiam esses barris (BARRETO FILHO \& LIMA, s/d, p.32I).

Por falta de banheiros públicos, era comum as pessoas defecarem e urinarem nos cantos, nas calçadas, no mato, nas praias, o que também concorria para aumentar a insalubridade da cidade (LEITE, I849, p.6). A higiene era precária também no que dizia respeito à venda dos alimentos, principalmente a carne, cujos bois e porcos eram abatidos em matadouros fétidos. Não menos higiênicos eram os açougues, impregnados de "pútridos miasmas, provenientes da porcaria que nelles existem." (Ibid.: I4). Fora a carne, que era vendida nos açougues, os outros produtos alimentícios eram, geralmente, vendidos domiciliarmente, à base dos gritos, a salvo de um eficaz controle sanitário. 
Nas ruas, além do lixo e excrementos, chegavam até a jogar cadáveres, abandonando-os à decomposição ou a eventuais recolhimentos. O relatório de um Chefe de Polícia ao Ministro do Interior João Octaviano Nebias assinalava que "naquelles tempos, quando um cidadão qualquer, pela sua pobreza, não podia fazer o enterro de um qualquer membro de sua família, usava de um meio prático: atirava com o cadaver á rua” (apud BARRETO FILHO \& LIMA,s/d, p.32I); isto a despeito da "facilidade com que a Policia proporcionava aos indigentes os meios de enterramento" (LIMA, I925, p.29).

Pelo que se depreende do relatório, cabia à polícia administrar o recolhimento e o enterramento dos cadáveres abandonados. Para corroborar tal constatação, encontramos um regulamento do depósito de cadáveres que fossem encontrados a esmo. $\mathrm{O}$ regulamento data de I854 e estipula que todo cadáver encontrado em "qualquer lugar" deveria ser enviado, pelo inspetor de quarteirão, ao "depósito da ladeira da Conceição", onde um dos médicos da polícia iria "verificar as causas da morte e época della", o que sugere haver cadáveres que passavam muitos dias expostos. Chegando ao depósito, o cadáver seria exibido ao público - convocado através de pregões - por vinte e quatro horas, para que alguém pudesse reconhecer sua identidade. Somente depois dessa exibição é que ele poderia ser enterrado nesse depósito, com ordem escrita do chefe de polícia. $^{2}$

Cadáveres insepultos eram uma exceção, o mais comum é que eles fossem sepultados; e o eram, via de regra, de urna maneira imprópria para os atuais padrões aceitáveis de higiene: em covas rasas dos terrenos de igrejas, hospitais e outros quaisquer. Os dois primeiros espaços eram os mais utilizados para a prática dos hábitos antihigiênicos arraigados da população. Nas igrejas, eram enterradas as pessoas de posses, salvo os suicidas. Os escravos, negros, pobres, pagãos e protestantes eram enterrados em covas rasas dos chamados campos santos ou cemitérios. Os falecidos em hospitais eram ali mesmo enterrados: em seus quintais (ORLANDI, I985, p.54-55; RENAULT, I969, p.I74).

Um relatório de uma comissão fiscalizadora da Câmara Municipal da Corte, em I837, referindo-se ao hospital da Santa Casa, dá-nos uma ideia do que era morrer nos ambientes hospitalares:

\footnotetext{
${ }^{2}$ Regulamento para a Casa de Deposito dos cadaveres, que forem achados, approvado pelo Aviso da Secretaria da Justiça de 4 de janeiro de I854. Assinado por Alexandre Joaquim de Siqueira, Secretario de Estado dos Negocios da Justiça.
} 
(..) a persistencia do desprezo com que continuão a serem ali tratados os mortos. A este respeito tudo se conserva no estado barbaro de todos os tempos... Cadaveres de ambos os sexos nus, amontoados em huma casa aberta... Expostos a todas as vistas... E depois lançados em huma cova rasa, onde não tem por cobertura mais do que 15 a 20 polegadas de terra. Que horror!!! Que perigo para a saude publica!!! ${ }^{3}$

As covas eram, geralmente, tão superficiais a ponto de um visitante estrangeiro relatar, em I828, que no cemitério da Igreja do Rosário, no Rio de Janeiro, as cabeças e os pés dos defuntos chegavam a ficar à mostra (apud ARAÚJO, I993, p.65). No começo do período colonial, esses mortos eram enterrados sem caixão, apenas tomavam um banho de cal viva. $\mathrm{O}$ forte calor da cidade e pouca largura das ruas agravavam o problema, contribuindo para tornar mais prejudicial à saúde "os gases sufocadores da vida” (Ibid.).

O hábito de se enterrar os mortos em igrejas era também uma herança remota do catolicismo, tal como as rodas dos expostos. Datava dos primeiros séculos da era cristã e espalhou-se por toda a Europa católica, vindo a ser combatido frontalmente pela racionalidade científica dos séculos XVII e XVIII. A Revolução Francesa, que fez ascender o terceiro estado contra a nobreza e o clero conservadores, não apenas proibiu os sepultamentos nos interiores das igrejas, como determinou, em sucessivas leis (I804, I805 e I808), que fossem criados cemitérios em áreas periféricas das cidades (SILVA, I977, p.72). No Brasil, proibição semelhante foi legalizada em I798, I80I e I808; mas a prática continuaria a ter uma larga sobrevida, a despeito das novas proibições que viriam a ser legalizadas (ARAÚJO, I958, p.I-5).

\section{A modernização capitalista promove a aliança entre o Estado e o higienismo}

Toda essa insalubridade que acabamos de retratar era depositária de uma sociedade de base estamental, patriarcal e ideologicamente ruralista. Não seriam simples leis a modificá-la, mas uma mudança infraestrutural, sob a forma de modernização capitalista, que foi atingindo o Brasil como espécie de sucursal da matriz europeia. A modernização surgiu lá e se espalhou pelo mundo, vindo também aportar entre nós. Não obstante, tivemos também o nosso

\footnotetext{
${ }^{3}$ Relatório de exame das prisões, carceres, hospitais e estabelecimentos de caridade apresentado á illustrissima Camara Municipal da Corte, pela Commissão por ella encarregada deste objecto. Rio de Janeiro: Typographia do Diario de N.L. Vianna, 1837, p.15.
} 
processo de modernização. Como o europeu, ele surgiu do fomento da infraestrutura. À medida que avançávamos economicamente, fazíamos o mesmo em outros sentidos: surgiam e se desenvolviam novas cidades; as antigas se multiplicavam em população, profissões, problemas... O novo ciclo econômico brasileiro, baseado nas minas auríferas das Minas Gerais, fez a colônia dar um significativo salto de qualidade, o qual nos trouxe um enriquecimento súbito - escoado quase que totalmente para fora, principalmente para a Inglaterra, a expensas de dívidas que Portugal tinha para com aquele país -; alavancou a modernização propriamente brasileira, de que antes falávamos; e transferiu a capital para o centro-sul, mais precisamente para o Rio de Janeiro, em 1763. Ser capital implica adquirir um novo status; ter aumentada a sua população; melhorado seus serviços públicos. A transferência da sede da colônia, por si só, era um fator de fomento de modernização.

Pouco tempo depois, a recém-capital iria sofrer um novo surto modernizante e grande aumento populacional, advindo de uma causa exógena: a transferência da Corte. Foi o nosso maior momento de ilustração até então, absorvido predominantemente pela cidade do Rio de Janeiro (COARACY, I965, p.82-83). Se quando do descobrimento e das primeiras imigrações colonizadoras vieram praticamente o populacho, os degredados, a ralé; dessa vez ocorria o contrário: a prevalência era dos ilustrados, técnicos, artistas, cientistas, burocratas de primeiro e segundo escalões, a família real e os nobres. A resultante imediata foi a mobilização da capital, que passou a ser um centro irradiador de luzes, ilustração. A chegada da família real e a nossa passagem à condição de Reino Unido, juntamente com Portugal e Algarve, fez-nos progredir tanto que apressou o nosso processo de Independência, o qual já vinha sendo desenvolvido, isoladamente, através de revoltas diversas, desde o século passado. Com a Independência, urgia-se construir um novo Estado e uma nova sociedade, enfim, uma nova nação. Fazer isto tendo como espelho os países mais adiantados, e foi neles que buscamos as adaptações para a nova ordem brasileira. Adaptamos, de imediato, sua teoria políticoideológica: o liberalismo. E o fizemos submetendo este a nossa cultura colonial; por isso o descaracterizamos em pontos fundamentais, principalmente ao mantermos a escravidão, a coroa e a sociedade estamental. Não obstante essa descaracterização, o liberalismo foi usado como arma fundamental contra o colonialismo (SANTOS, 1978, p.74); um liberalismo que alicerçou a "construção da ordem político-jurídica nacional" (WOLKNER, I998, p.80). Pouco a pouco, iríamos adaptando outros avanços modernizadores europeus, como seria o caso do higienismo. Mas conforme já o dissemos, houve um continuísmo dentro da descontinuidade, 
fazendo com que os avanços teóricos em termos de higienismo, de medicina social, convivessem durante grande parte do século XIX em promiscuidade com os hábitos antihigiênicos de outrora.

Chefes patrimonialistas e patriarcais em seus domínios rurais, os senhores de terras e escravos não tinham um interesse maior em exercer um domínio estreito sobre o Estado, que, como já assinalamos, era mais uma abstração, um ente fora da colônia, do que uma realidade concreta no dia a dia dos indivíduos. O cotidiano destes estava muito mais submetido aos ditames de seus respectivos senhores do que à legalidade estatal, fosse a metropolitana ou a advinda do Senado da Câmara. A pusilanimidade da vida pública trazia, em decorrência, a pusilanimidade do Estado. Entretanto, com o desenvolvimento da colônia a nível econômico, gerando modernização-urbanização-ciência, o Estado foi-se fortalecendo como ator político, concorrendo com o poder quase absolutista dos senhores rurais em seus domínios. A vida pública foi-se expandindo e, consequentemente, necessitando de um Estado mais forte e mais racional. Esse processo de expansão da vida pública e de fortalecimento do Estado fez com que os senhores rurais se interessassem - por necessidade de classe dominante - em estender os seus domínios locais sobre a máquina estatal. Com o desenvolvimento da Colônia, mormente a partir do ciclo do ouro, mais e mais os senhores rurais foram tomando as rédeas do Estado. Mas este tem também a sua autonomia, como Marx mostra em $O$ dezoito brumário de Luis Bonaparte, e, já no começo do século XIX, estava sendo disputado pelos tradicionais senhores rurais e pela ascendente e incipiente burguesia. A autonomia desse Estado começou a se dar a partir do momento em que se solidificou a nação brasileira, ainda sob o regime colonial. Nascidos em um mesmo território, vivenciando uma mesma cultura, desenvolveu-se o sentimento nativista nos brasileiros de várias classes sociais. A geração de riqueza interna, malgrado estar concentrada em poucas mãos, também foi um forte fator de expressão nacionalista. Desses ingredientes culturais e especificamente econômicos surgiu a vontade e a necessidade de libertação do jugo lusitano. Daí a importância libertária dos primeiros movimentos rebeldes pró-Independência que, embora derrotados, serviram de acumulação para o sete de setembro. A vinda da Corte para o Brasil, menos do que aumentar o controle sobre a colônia, recrudesceu em larga medida as bases para a Independência, pois alastrou significativamente a nossa modernização, a nossa racionalidade cientifíca. De modo que a Corte não pegou o Brasil em inércia, despertando-o para um novo tempo: capitalista, liberal, moderno e independente. Não! Ela apenas deu um impulso, apressou a nossa entrada nesse 
mundo. A Corte e a elevação do Brasil à categoria de Reino Unido foram fundamentais para o surgimento desse Estado de novo tipo de que tratamos há pouco, o qual seria, em grande parte, administrado pelos filhos dos senhores rurais, a maioria constituida de bacharéis em Direito, que ocuparia altos cargos no Conselho de Estado, além de Legislativos nacional e locais. Na operacionalidade da máquina estatal, estariam funcionários pequeno-burgueses e citadinos. Os senhores rurais propriamente ditos ainda teriam grande força nesse novo Estado de tendência burguesa. Força que se estenderia pela Primeira República e mais além. No entanto, eles, por si só, seriam incapazes de promover as transformações científicas que redundariam em uma nova ordem, racional, urbana e higienista. Mesmo por que estavam presos à velha ordem, tradicional, rural e insalubre. O Estado de tendência burguesa seria o ator principal das transformações da nova ordem: aglutinando os saberes científicos, instrumentalizando-os, tornando-os legais. A ciência veio para combater a velha ordem: anticientífica, estamental e religiosa. Ambos, novo Estado de tendência burguesa e racionalidade científica, que tinha o higienismo como ramo da medicina social e carro-chefe da medicalização citadina, eram frutos de uma mesma matriz: a modernização burguesa que vinha revolucionando a Europa a partir da etapa mercantil que levaria ao capitalismo. Tanto o novo Estado quanto o higienismo tinham interesse em combater a velha ordem, daí a aliança entre ambos.

O Estado se aproximou do saber médico - antes desprestigiado - e o prestigiou ante a sociedade capitalista que se estava formando. A modernidade capitalista é muitíssimo mais controladora do que o era a velha ordem, como demonstra Foucault em Vigiar e punir e em As verdades e as formas jurídicas, por exemplo. Capitalismo implica maximização da produtividade e concentração urbana, fatores que requerem higiene, controle médico, medicina social; requerem a evitação de epidemias, como a peste negra, que dizimava grande parte da população europeia na Idade Média. Os trabalhadores da sociedade capitalista precisam ser sadios para produzirem o máximo e o melhor possíveis. O surgimento da medicina social se fez materialmente necessário para prevenir e curar as doenças da sociedade industrial capitalista, a qual provocou também a necessidade do surgimento de várias outras ciências, em diferentes ramos de atividade, como nos dá conta George Rosen.

Historicamente, o conceito de medicina social apareceu como resposta aos problemas de doenças criadas pela industrialização. Em grande parte, a 
história da medicina social é a história da política social (bem-estar) (...) Baseado em dois pilares, a medicina e a ciência social, o conceito de medicina social só poderia se tornar mais preciso com o avanço da medicina e com o desenvolvimento da ciência social (...) A antropologia, a psicologia social, a sociologia e a economia são importantes para este campo quanto os vários ramos da medicina (ROSEN, 1979, p.I38).

A medicina moderna deixou de ser individualista, como era na velha ordem, e passou, necessariamente, a ser social, sob a forma de biopolítica, por exigência da sociedade industrial, do capitalismo.

Minha hipótese é que com o capitalismo não se deu a passagem de uma medicina coletiva para uma medicina privada, mas justamente o contrário; que o capitalismo, desenvolvendo-se em fins do século XVIII e inicio do século XIX, socializou um primeiro objeto que foi o corpo enquanto força de produção, força de trabalho. O controle da sociedade sobre os indivíduos não se opera simplesmente pela consciência ou pela ideologia, mas começa no corpo, com o corpo. Foi no biológico, no somático, no corporal que, antes de tudo, investiu a sociedade capitalista. O corpo é uma realidade bio-política. A medicina é uma estratégia bio-política (FOUCAULT, 1979, p.80).

Portanto, a modernização capitalista, traduzida por ciência, industrialização e urbanização, trouxe grande fomento à medicina social e aos médicos. A vida nas cidades exige mais disciplina, mais higiene, do que no campo. Neste, havendo uma insalubridade que impeça a convivência social, é mais fácil mudar as pessoas de lugar. Além disso, no campo, havía bem menos aglomeração de pessoas do que nas cidades mais desenvolvidas, o que fazia com que a produção da poluição dos homens fosse menor. Havia bem maior circulação de ar. As pessoas viviam ao ar livre. As cidades implicam acúmulo de mais e mais pessoas; concentração. Nessas condições, o nível de poluição determinado pelos homens aumenta consideravelmente, aumentando os riscos de doenças. A modernização produziu a urbanização e o caos urbano; produziu também antídotos a isto, o mais eficaz parece ter sido a medicina social, com seu higienismo, não foi tão-somente uma maneira científica de se combater as doenças e promover a saúde, mas também de disciplinar as massas para o 
mercado. Em uma sociedade que teria a necessidade vital do trabalho assalariado, fazia-se premente o controle racional das massas e o higienismo foi utilíssimo nesse propósito, daí a sua aliança com o Estado burguês. Caso continuasse a infraestrutura camponesa, o higienismo não teria surgido, pelo menos não com o mesmo ímpeto. O médico continuaria a ter um poder diminuto e os senhores rurais tenderiam a manter sua hegemonia, em detrimento da ciência. Os padres, a religião, também continuariam a gozar de prestígio e poder dogmáticos. Com a modernização, o médico, como os cientistas em geral, passaria, no decorrer do período imperial e início da república, a assumir um status equivalente ao do padre no período colonial. Passaria a deter um saber fora do alcance do senso comum. Mais saber, mais poder, e vice-versa, como salienta Foucault em sua "teoria" dos micropoderes (FOUCAULT, I979). De maneira que, a modernização, tendo como mote principal a industrialização, fez a cidade ficar mais forte do que o campo, o trabalho intelectual mais importante do que o manual, o Estado mais autônomo frente aos senhores rurais, os cientistas mais prestigiados do que os empiristas (isto sobretudo na área médica). Toda essa racionalidade, esse avanço modernista, que no Brasil chegaria com acentuado atraso, beneficiaria sobremaneira a mulher e a criança, penetrando direta e cotidianamente na família, em detrimento do chefe patriarcal e das ideologias e costumes ruralistas. Cabe salientar que a criança era a principal vítima do caos de insalubridade que registramos mais atrás. Muitas não resistiam e morriam em meio tão inóspito à sua sobrevivência. As estatísticas da época apontavam como principal causa mortis na primeira infância a falta de higiene, fosse aquela que atingia diretamente a criança, como doenças e maus hábitos higiênicos ou, indiretamente, através do meio ambiente insalubre: casas sem esgotos, sem água encanada, mal arejadas, sujas, fétidas, contendo miasmas, etc. A família citadina deixaria de ser essencialmente privada, isto é, presa do patriarcalismo, para tornar-se suscetivel a influências do mercado, dos valores emanados deste.

A família é atingida pelo mercado e, em um processo dialético, causa transformações em seus membros no sentido de adaptá-los ao mercado. Ou seja, a família é uma vítima do mercado e, nessa condição, toma-se um cúmplice deste, um agente, um, como diria Althusser, aparelho ideológico. $\mathrm{O}$ mercado não veio libertar a família do patrimonialismo, do rígido controle clássico, veio apoderar-se dela, transformá-la em seu objeto de exploração, diminuindo o tempo que lhe pertencia, enquadrando-a em normas, leis, horários, disciplinas (DONZELOT, 1980, p.I3). 
Essa influência do mercado sobre a família tradicional, que se ía desenvolvendo durante o período imperial, traria, por conseguinte, uma maior força ao Estado em seu processo de aburguesamento, pelo fato de os citadinos passarem a ser doutrinados pelos valores mercadológicos e pelo fato de a máquina estatal estar voltada para adequar-se às transformações materiais da sociedade. Estar mais forte nesse processo de aburguesamento e mais forte enquanto máquina de poder-saber, facilitava o Estado ter maior autonomia para encetar uma aliança com o higienismo (e com a ciência em geral) tendo por escopo comum a construção de uma ordem no sentido das transformações oriundas das revoluções burguesas.

\section{A aliança entre o Estado e o higienismo em prol da ordenação da vida pública}

Com a transferência da Corte, antigos entraves urbanos que se perpetuavam sem soluções adequadas tiveram que ser equacionados e resolvidos - vários o foram - a toque de caixa. Afinal de contas, os novos hóspedes do Rio de Janeiro, em grande quantidade e de nobre linhagem, não podiam ter uma qualidade de vida tão abaixo da que tinham na metrópole.

Os problemas demográficos criados pela chegada da Corte e o ritmo econômico imprimido ao Brasil pelo capitalismo europeu, especialmente o inglês, acentuaram as deficiências urbanas do Rio. Os aristocratas tinham hábitos de consumo, lazer, higiene, moradia, etc. que não encontravam satisfação no bisonho funcionamento da cidade, cuja rede de serviços urbanos necessitava modernizar-se (COSTA, 1979, p.52).

Sabemos que D. João VI, logo em seus primeiros dias no Rio de Janeiro e ao longo de sua efêmera permanência, imprimiu à cidade vários avanços modernizadores, nos campos da educação (mormente a nível superior), da ciência, da arte e da máquina estatal. A insalubridade não poderia continuar como antes nesse novo meio cultural, mas continuaria por um largo período, sendo combatida mais nas leis do que na prática. $\mathrm{O}$ importante a destacar-se, em termos gerais, e em se tratando especificamente de higienismo, é que a presença da Corte fortaleceu as bases da ciência e da aliança desta com o Estado de novo tipo (sob influência do liberalismo burguês, embora longe de perder a influência do tradicionalismo) que estava sendo desenvolvido.

Logo em seus primeiros dias no Rio de Janeiro, D. João VI determinou ao recémnomeado fisico-mor Manoel Vieira da Silva que, juntamente com a comunidade médica, 
providenciasse um relatório dando conta da situação sanitária da cidade e de medidas para combater a insalubridade. Nesse relatório, que já era uma preliminar manifestação do poder dos médicos, da medicina social, e de sua aliança com o Estado de novo tipo que se vinha formando, estavam sugeridas propostas que caracterizavam a medicina não mais como a ciência individualista dirigida apenas a pacientes específicos, mas a coletiva, dirigida a toda a cidade, isto correspondía ao nosso início de experiência enquanto medicina social, biopolítica, biopoder. Nas propostas gerais do relatório, os médicos se apresentavam como agentes formuladores de políticas públicas, sugerindo que:

Devem-se aterrar os pântanos emanadores de gases pestilentos, encanar as águas, demarcar as ruas e lugares de construção, cuidar dos cemitérios, combater o comércio de alimentos estragados, controlar os matadouros e açougues, fiscalizar os portos, criar lazaretos para quarentena e controlar o exercício da medicina, criando meios de formar bons médicos. (ORLANDI, I985, p.54).

Através do Decreto de 28 de julho de I809, D. João VI criava o cargo de "Provedor Mor da Saude da Corte e do Estado do Brazil", "dezanexando-o da inspecção das Câmaras" e dando-lhe toda "Jurisdicção necessaria, a fim de que por si e seus Delegados se conserve a saude publica, pondo-se em pratica no que for applicavel o Regimento do Provimento da Saúde”. Na prática, estava sendo criado o embrião do futuro ministério da saúde, com autonomia diante das Câmaras Municipais de então. Ao invés destas, como era corrente anteriormente, o Decreto nomeava o fisico-mor Manoel Vieira da Silva, um médico, para elaborar "hum novo Regimento" que traçasse as normas de saúde pública para o Brasil como um todo.

O novo regimento veio sob a forma do Alvará de 22 de janeiro de I8Io, também emitido por D. João VI, através do qual ficava revogado o regimento de I6 de maio de I744, elaborado pela Real Junta do Proto-Medicato, extinta pelo Alvará de 7 de janeiro de I809. D. João VI fazia questão de enfatizar que o regimento “me foi proposto pelo Fyzico Mór do Reino", o que era uma maneira de se prestigiar a medicina e os médicos. O seu primeiro item criava o cargo de "Juiz Commissario Delegado do Fyzico Mór do Reino", que teria necessariamente que ser médico, "formado na Universidade de Coimbra ou em outra qualquer que se crear neste Reino”. Este Juiz Comissário teria a incumbência de fiscalizar a saúde pública em todo o 
território nacional, com o poder para cassar licença de profissionais de saúde, fechar boticas, inspecionar fabricação e comércio de medicamentos, entre outras atribuições.

Por meio desse alvará, o Estado buscava um controle mais seletivo e estreito sobre a saúde pública, fazendo a figura do fisico-mor e seus delegados ocuparem o lugar da extinta Real Junta do Proto-Medicato (SILVA, 1975, p.45). Não obstante, haveria uma sobrevida para os paramédicos, que seriam sufocados pelas futuras hegemonia e refutação dos médicos acadêmicos, formados, em sua grande maioria, pelas futuras Faculdades de Medicina do Rio de Janeiro e da Bahia.

Em I8I2, foi publicado no Brasil o livro de Cabanis - membro da Escola e Sociedade de Medicina de Paris e da Sociedade Filosófica de Filadelfia -, intitulado Do gráo de certeza da medicina, que consistia em uma das primeiras publicações em terras brasileiras a defender com veemência o status científico da medicina e o monopólio do médico diante de seus concorrentes leigos.

(...) para salvar o paciente de tantas determinações cegas, vacillantes, e contraditorias, he necessario huma authoridade, que captive sua confiaça, que inspire respeito a tudo que o cerca que confunda a ignorancia com o ascendente das luzes e que dê ao tratamento hum espirito methodico, e de unidade: he preciso que hum mande, afim de que todos não queirão mandar ao mesmo tempo. Eis o verdadeiro caracter do Medico; eis o que de ninguem se póde esperar se não delle (...) por quanto a Medicina, bem longe de ser, como affirmão alguns declamadores, hum flagello da humanidade, he pelo contrario sua esperança, e sua salvaguarda; ella lhe promette para o futuro socorros, que de dia em dia se devem tornar mais extensos e mais efficazes (CABANIS, I8I2,p.85).

A Independência ensejou a que houvesse um esforço na construção de uma nova ordem, embora, mais uma vez insistimos, impregnada pela tradição colonial, inclusive em termos de saúde pública. Basta verificar que os exemplos gritantes de insalubridade que citamos anteriormente, como a falta de rede doméstica de esgotos e os "tigres", ainda vigiriam em na segunda metade do século XIX.

Em I825, uma portaria de D. Pedro I proibia sepultamentos em igrejas e determinava que fosse construído um cemitério. Era uma lei que vinha reforçar outra de igual teor, datada 
de I8OI (ORLANDI, I985, p.55). Não obstante, a prática dos sepultamentos em igrejas continuaria e novas leis e relatórios viriam combatê-la. Em I830, a Comissão de Salubridade Geral da recém-criada (I829) Sociedade de Medicina e Cirurgia do Rio de Janeiro apresentava um relatório no qual, entre outros itens referentes ao aspecto sanitário geral da cidade, abordava a questão dos sepultamentos em igrejas, pregando a sua extinção imediata como um serviço a bem da saúde pública (TEIXEIRA, I888, p.400). $\mathrm{Na}$ sessão de 04 de outubro do mesmo ano, a Câmara Municipal do Rio de Janeiro aprovou um Código de Posturas para a cidade, o qual, por sua vez, seria aprovado pela Regência em 26 de janeiro de I832, através da Decisão de Governo número 44. Esse Código legalizava várias das sugestões contidas no relatório dos médicos apresentado a D. João VI em I808, ao qual aludimos anteriormente. O Código procurava englobar quase tudo o que dizia respeito à saúde pública da cidade e, ainda, penetrava nas instituições, nas casas comerciais e industriais, nos lares; era a polícia médica e a medicina social já ensaiando o seu poder social em aliança com o Estado. Não por acaso, o primeiro título do Código referia-se especificamente a "cemitérios e enterros". O primeiro parágrafo desse título era categórico em afirmar:

Fica absolutamente prohibido enterrarem-se corpos dentro das Igrejas, ou nas sacristias, claustros dos Conventos, em quaesquer outros lugares nos recintos dos mesmos: os administradores das Igrejas, que violarem esta Portaria, pagarão $30 \$ 000$ de condenação, e os coveiros, que fizerem as covas, terão oito dias de cadêa. Esta disposição terá seu effeito sòmente depois de estabelecidos os cemitérios fóra da cidade, ou de se ter designado pela Câmara Municipal os lugares, em que se devam fazer os enterros provisoria, ou definitivamente.

Mais cinco parágrafos tratavam do mesmo tema, determinando, entre outras posturas, que

todos os corpos que se enterrarem, deverão ficar abaixo da superfície da terra pelo menos seis palmos, sendo a terra bem socada e devendo além disto não haver mais de um corpo em cada cova, salvo se entre um e outro corpo ficar uma camada de terra da altura de outros seis palmos; nenhum corpo será dado á sepultura sem prévia participação ao Juiz de Paz da freguesia, declarando-se o lugar, em que vai fazer-se o enterro, apresentando-se certidão 
do Facultativo, que o houver assistido, no qual este declare a enfermidade, de que morreu e a sua duração, assim como a hora da morte, e a morada do falecido.; Nenhum corpo de qualquer tamanho e côr, que seja, será conduzido á sepultura sem ser o caixão fechado, e coberto com panno, quando a enfermidade de que fallecer puder produzir contagio immediato, o que o Medico verificador do obito também attestara: fora deste caso se poderão conduzir os cadaveres em redes, indo bem amortalhados: os que se acharem culpados por contravenção a esta postura pagarão 30 \$ooo de condemnação.

O Código regulamentava venda de remédios, obrigava aos moradores manter desobstruídas as valas e canos de sua casa para darem a vazão à passagem das águas pluviais; normatizava a higienização de matadouros, açougues, comércio, indústria e hospitais; determinava uma futura transferência dos hospitais para a periferia da cidade; proibia que qualquer pessoa desembarcasse de navios, sem haver antes uma inspeção e autorização médica; proibia atirar-se lixo ou entulho nas vias públicas; proibia a criação de porcos nos quintais ou quaisquer outras partes das casas; regulamentava o alinhamento das ruas e a edificação das casas particulares e comerciais; obrigava os moradores a manterem limpas as suas calçadas; proibia cães soltos pelas ruas; proibia "vozerias nas ruas, injurias, e obscenidades contra a moral publica."

A questão dos sepultamentos em igrejas e hospitais somente começaria a ser mitigada, na prática, a partir de 2 de julho de I839, quando a Santa Casa inaugurou o Campo Santo da Misericórdia em lugar situado no atual bairro do Caju, então Ponta do Caju. Em I6 de dezembro de I85I, o Decreto número 842, dava ao Campo Santo a denominação de Cemitério de São Francisco Xavier e fundava outro cemitério, o São João Batista, em Botafogo. Dois dias depois, outro decreto, de número 843, passava para a Santa Casa a concessão de administrar esses cemitérios e serviços funerários por cinquenta anos. Concessão que se vem renovando desde então (ORLANDI, I985, p.55-56; TEIXEIRA, I888, p.400).

Em I $^{\circ}$ de novembro de 1840 , eram fechados os jazigos e catacumbas do hospital da Misericórdia (TEIXEIRA, I888, p.400) e, em I6 de março de I850, era banido o sepultamento no interior das igrejas (RENAULT, 1969, p.56). Essas medidas representavam uma vitória significativa sobre uma tradição de séculos. A essa altura, os médicos já estavam bem mais fortalecidos do que no início do século XIX, com considerável presença nas políticas públicas das cidades mais desenvolvidas. Como resultado desse avanço, foi fundada, em 30 de junho de 
I829, a então denominada Sociedade de Medicina e Cirurgia do Rio de Janeiro que, em I835, mais fortalecida e abrangente, passaria a denominar-se Imperial Academia de Medicina, tornando-se, em 2I de novembro de I889, com a chegada da República, a Academia Nacional de Medicina (SINGER ET AL., I978, p.IOI-IO4).

Por decreto de 15/I/I830, os estatutos da Sociedade de Medicina do Rio de Janeiro especificaram seu funcionamento. Deveria ser uma espécie de consultaria do governo para assuntos relacionados à saúde pública. Em I835, transformada na Academia Imperial de Medicina do Rio de Janeiro: seus novos estatutos, aprovados por decreto de 8/5/1835, definiram-na como especialmente instituída para responder às perguntas do governo principalmente com relação à saúde pública (privilegiando as epidemias), de forma que, ao lado da Faculdade de Medicina, a Academia caracterizou-se, oficialmente, como instância especializada na produção de um saber com vistas a viabilizar a perspectiva política da higienização do espaço urbano (RODRIGUES, 1997, p.I06).

A criação da Sociedade de Medicina do Rio de Janeiro representou um importante passo para o reconhecimento da classe médica em direção ao monopólio do exercício legal da medicina. A SMRJ correspondía “ao início da institucionalização da higiene pública no Brasil”, tendo sido constituida "segundo as concepções políticas e epistemológicas do movimento higienista europeu do final do século XVIII, particularmente o françês" (FERREIRA, I996, p.68-69).

Até I828, quando foi extinta a Fisicatura-mor, cartas de referência, atestados de aprendizagem de ofício ou de conhecimentos empíricos permitiam a barbeiros-sangradores, cirurgiões-barbeiros ${ }^{9}$, boticários, parteiras, dentistas práticos e curandeiros em geral ingressarem no mundo das práticas oficiais de curar. Os regulamentos que vêm a substituir a legislação da Fisicatura e da Provedoria-mor, em I832, alteraram o antigo quadro geral. A partir daí, de todos os diferentes ofícios de curar, os únicos que continuaram a ser reconhecidos, além, é claro, dos médicos, foram os cirurgiões, os boticários e as parteiras (que somente poderiam atuar dentro de indicações e das determinações da medicina ofical) (WITTER, 2005, p.I9-20). 
A despeito deste reconhecimento legal, as demais práticas continuaram atuando na ilegalidade, adentrando o século XX (WITTER, 2005, p.20).

Paralelamente à legalização de posturas e ofícios, a medicina social seguia consolidando sua força no corpo do Estado, principalmente através da fundação, em I850, da Junta de Higiene Pública, que correspondia a uma espécie de Secretaria de Saúde da época (SINGER ET AL., I978, p.99). Justamente nesse ano de I850, uma epidemia de febre amarela apareceu pela primeira vez na cidade do Rio de Janeiro, causando "4.I6o mortes em população de cerca de 200.000 habitantes, em pouco mais de três meses" (ARAÚJO, I958, p.6).

Apesar dos avanços da medicina, a cidade ainda deixava muito a desejar em termos de saúde pública. A primeira epidemia de febre amarela, e outras que viriam, testemunhou tal assertiva. Já indicamos, mais atrás, que a falta de água encanada, de esgotos domiciliares e os "tigres" eram realidades que ultrapassavam meados do século XIX e que iriam ter como companhia agravante o surgimento, a partir dos anos I860, e a proliferação dos cortiços emanadores de insalubridade e marginalidade. $\mathrm{O}$ fato é que os saberes acadêmicos, a despeito do progresso da ciência médica e da criação de duas faculdades de medicina, ainda não estavam suficientemente fortalecidos e confiáveis para obstarem a rivalidade dos saberes dos práticos e trazer a totalidade da clientela destes para os médicos.

Sabe-se que apesar dos esforços da medicina acadêmica, os elementos que a diferenciavam de outras propostas terapêuticas (fossem científicas, pseudocientíficas, empíricas ou mesmo saberes dos práticos e empíricos com base nos manuais de medicina), do ponto de vista da eficácia, eram ainda muito poucos. Os avanços dos conhecimentos de anatomia e fisiologia, embora tivessem melhorado consideravelmente o campo da cirurgia - ao que se somaram, em I846, a descoberta da anestesia, e em I865, a assepsia - ainda não haviam dado grandes resultados no tocante às terapias. Os remédios conhecidos eram limitados e pouco ou nada se sabia sobre as causas das doenças. Mesmo na segunda metade do século, as purgas e sangrias ainda constituíam uma boa parte dos tratamentos, as mezinhas receitadas eram compostas de elementos geralmente simples e muitas vezes semelhantes àqueles usados pelos curandeiros (WILKER, 2000, p.I88). 
Várias teses da Faculdade de Medicina do Rio de Janeiro denunciavam as más condições de higiene da cidade. Uma delas, defendida em I876, portanto já no último quartel do século XIX, afirmava que "si continuarem-se a repetir os tristes factos que nestes últimos annos temos observado, maxime os que se deram em i873 e i876, veremos esta cidade adquirir tal fama de insalubridade que ficará despovoada; sendo talvez mister abandonal-a.” A seguir, são propostas várias medidas saneadoras: criação de abastecimento de água potável, remoção do matadouro para fora da cidade, aterramento de todos os pântanos, demolição dos morros do Castelo e de Santo Antônio, remoção dos cemitérios para longe da cidade, extinção dos cortiços, construção de obras de esgotos, arborização das praças e alargamento das ruas, conservação e replantio das florestas que cercavam a cidade, controle sobre a prostituição para combater a sífilis, limpezas dos rios, praias e ruas, proibição de aterros de lixos, organização de socorros médicos a domicílio, proibição de se criarem hospitais e casas de saúde na área central da cidade, combate ao consumo de bebida alcoólica, fumo e café, vacinação obrigatória, proibição de depósito de porcos perto de lugares populosos, maior fiscalização sobre o estado dos alimentos, fiscalização sobre a saúde das vacas leiteiras, sobre as amas de leite e sobre a higiene das escolas (TEIXEIRA, I888,p.III-II3).

Em 3 de fevereiro de I886, o Decreto 9554 reorganizou o serviço sanitário do Império, através de um regulamento que era uma versão atualizada do Código de Posturas de I832, concedendo ainda mais poderes à polícia sanitaria no que dizia respeito ao controle das saúdes pública e privada. A partir de então, especificamente na cidade do Rio de Janeiro, mais medidas higienistas seriam tomadas como resultado da aliança entre o Estado e a medicina social. Medidas essas que adentrariam o século XX, sendo a Reforma Pereira Passos o exemplo marcante de uma síntese de conjugação de esforços estatais e higienistas como forma de se ordenar o caos de insalubridade e de instabilidade social e urbanística que ainda persistia na cidade do Rio de Janeiro.

\section{Conclusão}

Buscamos no decorrer deste trabalho estabelecer uma relação de causalidade entre higienismo e modernização capitalista. Ou seja, defendemos o ponto de vista de que o primeiro fenômeno somente aconteceu por ter sido consequência do segundo. A modernização capitalista a que nos referimos é aquela que se desenvolveu em suas sucessivas 
fases mercantil e industrial. A fase mercantil já foi um fator condicionante para o surgimento e desenvolvimento das cidades modernas, sedes das relações econômicas, políticas, burocráticas e ideológicas. Nessas cidades a vida social exigia uma ordenação mais rígida do que nas áreas rurais. Passou a haver um controle mais estreito sobre o corpo, no que dizia respeito à evitação de doenças e, principalmente, naquilo que tangia ao enquadramento dos indivíduos à nova ordem burguesa. Esse controle mais estreito corresponde ao que Foucault denomina biopolítica ou biopoder (FOUCAULT, I988), algo que surgiu justamente nesse momento de modernização das relações sociais.

A urbanização, fortemente impulsionada pela Revolução Industrial, fez a mediação entre a modernização capitalista e o higienismo, sendo efeito da primeira e propulsora do segundo. Não por acaso o higienismo teve o seu epicentro nas grandes cidades, aquelas alavancadas pela urbanização. Nessas cidades, o trabalho (assalariado) era não somente o gerador de riquezas - através da exploração das mais-valias absoluta e relativa - mas também o principal elemento disciplinador de massas. Não trabalhar implicava não produzir riquezas para a acumulação da burguesia e tornar-se perigoso à manutenção da ordem. Surgiu uma distinção entre os que trabalhavam e os que não o faziam, estes eram classificados sob epítetos os mais diversos: vadios, vagabundos, mendigos, gatunos, capoeiras, prostitutas... Fazia-se mister combatê-los severamente, à base da repressão, como modo de se evitar que disseminassem a desordem. Esses marginais eram também vistos como os principais propagadores de endemias, a partir de seus locus de moradia, geralmente cortiços (a partir de meados do século XIX), nos quais viviam dezenas de pessoas, em família ou não, em ambiente de promiscuidade. Era comum nos relatórios dos chefes de polícia da Corte aparecer espaços consideráveis para se verberar contra os marginais e os cortiços, pregando-se a coerção policial como solução privilegiada para tais males. $\mathrm{O}$ advento e o fomento irreversíveis do capitalismo instituiram o discurso pró-ordem, tanto no corpo do Estado como em vários segmentos elitistas da sociedade civil, destacando-se dentre esses a medicina social e o seu higienismo.

Se na velha ordem estamental não havia uma necessidade de se instalar o higienismo e se combater os homens livres que não trabalhavam - uma regra geral, pois o trabalho era algo depreciativo e quase que uma exclusividade dos escravos -, na nova ordem em processo de aburguesamento passou a existir uma inversão desses valores. A construção dessa ordem e o combate aos marginais e seus riscos de desordem e transmissão de doenças foram 
extremamente utilitaristas para unir o Estado e o higienismo. Essa união foi um produto da modernização capitalista e seria inviável de ser encetada na velha ordem rural e estamental.

\section{Referências Bibliográficas}

ARAÚJO, Carlos da Silva. O cirurgião-mor José Corrêa Picanço e o Sepultamento nas Igrejas. Separata da Revista Laboratório Clínico, $3^{\circ}$ semestre de I958, p. I-5.

ARAÚJO, Emanoel. O Teatro dos Vícios. Transgressões e Transigência na Sociedade Colonial. Rio de Janeiro: José Olympio, 1993.

BARRetO FILHO, MeIo; LIMA, Hermeto. História da Polícia do Rio de Janeiro. Aspectos da Cidade e da Vida Carioca, I565-I83I, Rio de Janeiro: Editora A Noite, s/d.

BIBEYROLLES, Charles. Brasil pitoresco. Descrições. Viagens. Colonização. Instituições. São Paulo: Martins, I94I.

BUNBURY, Charles James Fox. Narrativa de Viagem de um Naturalista Inglês ao Rio de Janeiro e Minas Gerais. Rio de Janeiro: Imprensa Nacional, 1940.

CABANIS, P.J.G. Do Gráo de Certeza da Medicina. Rio de Janeiro: Imprensa Régia, I8I2.

COARACY, Vivaldo. Memórias da cidade do Rio de Janeiro. V. 3. Rio de Janeiro: José Olympio, 1965.

COSTA, Jurandir Freire. Ordem médica e Norma Familiar. Rio de Janeiro: Graal, 1979.

DEBRET, Jean Baptiste. Viagem Pitoresca ao Brasil, tomo I, volumes I e II, São Paulo: Martins,1940.

DONZELOT, Jacques. A Policia das Famílias. Rio de Janeiro: Graal, 1980.

FARINHA, João Pires. Questões Hygiénicas. Mephitismo Animal. Esgotos do Rio de Janeiro e sua Influencia sobre a Saude Publica. Alguns Conselhos Hygienicos ao Povo. Rio de Janeiro: Typografia Nacional, I883.

FERREIRA, Luiz Otávio. O Nascimento de uma Instituição Científica. O Periódico Médico Brasileiro da Primeira Metade do Século XIX. São Paulo: Tese de Doutoramento em História Social, FFLCH-USP, 1996.

FOUCAULT, Michel. A Verdade e as Formas Jurídicas. Rio de Janeiro: NAU, I976.

FOUCAULT, Michel. O nascimento da medicina social. In: MACHADO, Roberto (Org.). Microfisica do Poder. Rio de Janeiro: Graal, 1979. 
FOUCAULT, Michel. História da Sexualidade I. A Vontade de Saber. Rio de Janeiro: Graal, 1988. FOUCAULT, Michel. Vigiar e Punir. Rio de Janeiro: Vozes, 2004.

LEITE, Tobias Rabello. Breves considerações acerca da política sanitária. Tese à Faculdade de Medicina do Rio de Janeiro. Rio de Janeiro, Typografia do Archivo Médico Brasileiro, I849. LIMA, Hermeto. História da polícia do Rio de Janeiro. Vida Policial, anno I, n.23, ,1925,22-39.

MACHADO, Roberto et al. Danação da Norma. Medicina Social e Constituição da Psiquiatria no Brasil. Rio de Janeiro: Graal, 1978.

NASCIMENTO, Alfredo. A medicina nos Tempos Coloniais do Brasil. Revista Symiatria, v. VII, 1915.

- Quatro Séculos de Medicina no Brasil. Rio de Janeiro: Imprensa Nacional,I929.

ORLANDI, Orlando V. Teoria e Prática do Amor à Criança. Introdução à pediatria social no Brasil, Rio de Janeiro, Zahar, 1985.

RENAULT, Delso. O Rio Antigo nos Anúncios dos Jornais. Rio de Janeiro: José Olympio, 1969. Rio de Janeiro: a vida da cidade refletida nos jornais (I850-I870). Rio de Janeiro, Civilização Brasileira, 1978.

ROCHA, José Martinho da. Introdução à História da Puericultura e Pediatria no Brasil (I50o-I882). Rio de Janeiro: Nestlé,I947.

RODRIGUES, Cláudia. Lugares dos Mortos na Cidade dos Vivos. Rio de Janeiro: Prefeitura da Cidade do Rio de Janeiro, 1997.

ROSEN, George. Da Polícia Médica à Medicina Social. Rio de Janeiro: Graal, 1979.

SANTOS, Wanderley Guilherme dos. Ordem burguesa e liberalismo político. São Paulo: Duas Cidades, 1978.

SANTOS FILHO, Lycurgo. História da Medicina no Brasil. Do Século XVI ao Século XIX. $\mathrm{I}^{\circ}$ tomo. São Paulo: Brasiliense, s/d.

SILVA, Maria Beatriz Nizza da. "Análise da estratificação. O Rio de Janeiro de I808 a I82I, Faculdade de Filosofia, Letras e Ciências Humanas da Universidade de São Paulo, Departamento de História, Boletim Nova Série, v.7, n. 6,1975.

. Cultura e Sociedade no Rio de Janeiro (I808-I82I). São Paulo: Companhia Editora Nacional,1977.

SINGER, Paul et al. Prevenir e Curar. Rio de Janeiro: Forense Universitária,I978.

TEIXEIRA, José Maria. Mortalidade das Crianças no Rio de Janeiro. Rio de Janeiro: Tese de Doutorado em Medicina, Faculdade de Medicina do Rio de Janeiro, I888. 
VIOTTI, Ana Carolina de Carvalho. As práticas e os saberes médicos no Brasil colonial (I677-I808). Dissertação em História. Faculdade de Ciências Humanas e Sociais. Universidade Estadual Paulista, Franca, 2012.

WEBER, Max. Os três tipos puros de dominação. In: COHN, Gabriel (Org.). Weber. Coleção Grandes Cientistas Sociais. São Paulo: Ática, I979.

WILKER, Nikelen A. Curandeirismo: um outro olhar sobre as práticas de cura no Brasil do século XIX. Vidya. Leituras de História, n.34, 2000.

WITTER, Nilelen Acosta. Curar como arte e ofício: contribuições para um debate historiográfico sobre saúde, doença e cura. Tempo, Rio de Janeiro, n.I9, p.I3-25, 2005. WOLKNER, Antônio Carlos. História do Direito no Brasil. Rio de Janeiro: Forense, I998. 